\title{
Menumbuhkan Keterampilan Berpikir Tingkat Tinggi melalui Open Ended Problem
}

\author{
Apdwi Syaeruldinata ${ }^{1}$, Abdur Rahman As'ari², Abadyo $^{2}$ \\ ${ }^{1}$ SMP Negeri 3 Gangga Kabupaten Lombok Utara \\ ${ }^{2}$ Pendidikan Matematika-Universitas Negeri Malang
}

\begin{tabular}{l} 
INFO ARTIKEL \\
\hline Riwayat Artikel: \\
Diterima: $13-08-2018$ \\
Disetujui: $13-08-2019$ \\
\hline
\end{tabular}

\section{Kata kunci:}

open ended problem; higher order thinking; open ended problem; berpikir tingkat tinggi

\author{
Alamat Korespondensi: \\ Apdwi Syaeruldinata \\ Pendidikan Matematika \\ Universitas Negeri Malang \\ Jalan Semarang 5 Malang \\ E-mail: apdwisyaeruldinata@gmail.com
}

\begin{abstract}
ABSTRAK
Abstract: This study aimed to describe both process and result of the development of teaching materials used to enhance higher order thinking skills based on open ended problem and its products should be valid, effective and practice. This study adopted a 4D developmental model modified be 3D which comprises three stages: define, design, and develop. The results showed: (1) The teaching materials that have been develop declared valid with the mean score 3,30 , lesson plan declared valid with the mean score 3,125 , achievement test declared valid with the mean score 3,45 , (2) effectiveness characterized by whole class achievement test mean score obtained 78,83 , and whole class questionnaire mean score obtained 2,35 , (3) practicality of teaching materials characterized by observation sheet mean score for whole observer obtained 3,6, and (4) using open ended problem significantly enhances students higher order thinking skills, as well as students justify effectiveness of several procedure that is followed by appropriate arguments, integrate different characteristic within it's unity, also think creatively construct the problem themselves.
\end{abstract}

\begin{abstract}
Abstrak: Penelitian ini bertujuan untuk mendeskripsikan proses dan hasil pengembangan perangkat ajar untuk menumbuhkan keterampilan berpikir tingkat tinggi beracuan open ended problem yang valid, efektif, dan praktis. Penelitian ini merupakan bagian dari penelitian pengembangan menggunakan modifikasi model 4-D (four-D model) menjadi 3-D yang meliputi tahap penetapan (define), perancangan (design), dan pengembangan (develop). Hasil penelitian menunjukkan bahwa: (1) peragkat ajar yang dikembangkan valid dengan skor rerata 3,30 untuk bahan ajar; 3,125 untuk RPP; dan 3,45 untuk lembar tes hasil belajar, (2) perangkat ajar efektif ditandai dengan rerata skor tes hasil belajar seluruh siswa adalah 78,83, dan rerata skor respons keseluruhan siswa adalah 2,35 (3) bahan ajar praktis ditandai dengan rerata skor hasil observasi keterlaksanaan bahan ajar dari seluruh observer adalah 3,6, dan (4) penggunaan open ended problem memberi dampak yang signifikan dalam menumbuhkan keterampilan berpikir tingkat tinggi siswa. Siswa antara lain telah dapat menjustifikasi tingkat efektifitas dari beberapa alternatif prosedur yang ada disertai dengan argumentasi yang sesuai, siswa dapat mengaitkan unsur-unsur yang berlainan dalam sajian masalah dengan satu kesatuan strukturnya yang utuh dan mengorganisasikannya dalam menentukan penyelesaian, serta siswa berpikir kreatif ditandai dengan kemampuan mengonstruksi masalah sekaligus penyelesaiannya sendiri.
\end{abstract}

Salah satu tujuan pokok dalam mengajarkan matematika adalah mengembangkan kemampuan berpikir tingkat tinggi siswa (Polya, 1965). Hal ini menjadi penting karena pengetahuan yang diperoleh melalui proses berpikir tingkat tinggi akan bertahan lebih lama dibanding pengetahuan yang diperoleh melalui proses berpikir tingkat rendah seperti menghafal (Ali \& Mishra, 2014). Misalnya siswa yang belajar menurunkan rumus, akan menguasai pengetahuan dalam jangka panjang, selain mampu menggunakan rumus pada konteks yang berbeda. Melalui suatu penelitian meta analisis yang dilakukan disimpulkan bahwa penggunaan unsur berpikir tingkat tinggi dalam pembelajaran membantu meningkatkan prestasi belajar siswa (Hasim, Yasin, \& Rosli, 2015). 
Sejauh ini pembelajaran matematika belum optimal dalam mengembangkan keterampilan berpikir tingkat tinggi (Eggen \& Kauchak, 2010; Hare \& Puliam, 1980; Saido, Siraj, Nordin, \& Al-Amedy, 2015). Hal ini disebabkan antara lain karena kemampuan guru matematika dalam menerapkan strategi pembelajaran yang mengembangkan keterampilan berpikir tingkat tinggi masih rendah (Saido et al., 2015). Sejalan dengan hal ini, hasil penelitian lain juga menyimpulkan bahwa hanya 20\% dari semua pertanyaan yang diajukan guru di kelas memerlukan jawaban lebih dari sekedar mengingat fakta sederhana dan mengembangkan keterampilan berpikir tingkat tinggi siswa (Hare \& Puliam, 1980), sementara sebagian besar pengalaman belajar matematika siswa di sekolah menitikberatkan pada masalah-masalah yang well-defined (Eggen \& Kauchak, 2010). Masalah yang well-defined adalah masalah yang hanya memiliki satu solusi yang tepat dan metode tertentu untuk menemukan solusi tersebut.

Salah satu faktor penting yang harus diatasi dalam mengembangkan keterampilan berpikir tingkat tinggi adalah ketersediaan sumber belajar (Yen \& Halili, 2015) karena untuk mengajarkan berpikir tingkat tinggi diperlukan perbaikan sumber atau bahan belajar yang memadai (Zohar, 2004). Sumber belajar menjadi penting karena sebagian besar guru menggunakan sumber belajar seperti buku paket sebagai petunjuk utama dalam mengajar (Van de Walle, Karp, \& Bay-William, 2010). Untuk mengembangkan keterampilan berpikir tingkat tinggi perlu buku pedoman yang lebih spesifik dan khusus (Heong et al., 2011).

Unsur penting dalam bahan ajar adalah penyajian contoh masalah (worked problem) untuk menciptakan stimulus yang memadai (Suryadi, 2006). Masalah yang disajikan mengandung unsur konstruksi karena dasar teori dalam mengembangkan keterampilan berpikir tingkat tinggi bergeser dari paradigma transmitting information (hanya memberi pengetahuan) menjadi konstruktivisme (Yen \& Halili, 2015). Sajian masalah juga mesti menghadapkan siswa dengan masalah sehari-hari (Miri, David, \& Uri, 2007), dan mengakomodasi diskusi antar siswa dengan tugas-tugas yang memiliki kemungkinan lebih dari satu jawaban benar (Ali \& Mishra, 2014).

Masalah terbuka (open ended problem) memiliki potensi yang baik untuk mengembangkan keterampilan berpikir tingkat tinggi (Ali \& Mishra, 2014). Penelitian lain juga mendukung penggunaan tugas-tugas yang memiliki kemungkinan lebih dari satu jawaban benar (open ended mathematics problem), dan merekomendasikan penggunaan pendekatan open ended dalam pembelajaran matematika (Al-Absi, 2013). Hal ini disebabkan karena daya kreatif siswa akan diasah ketika dihadapkan dengan open ended problem yang memiliki kemungkinan lebih dari satu cara penyelesaian maupun jawaban benar. Berikutnya siswa didorong untuk mengevaluasi cara penyelesaian dan jawaban benar tersebut dengan membandingkan satu sama lain sehingga menghasilkan justifikasi, keefektifan, kesederhanaan, kemudahan, dan sebagainya. Untuk melakukan semua itu diperlukan kemampuan menjabarkan informasi pada sajian masalah (problem) menjadi lebih sederhana seperti petunjuk (clue), fakta (fact) maupun pengetahuan sebelumnya yang relevan untuk merumuskan langkah-langkah penyelesaian. Artinya kemampuan analisis siswa juga diasah dan dikembangkan. Dalam implementasi di kelas, siswa ditugasi memecahkan masalah open ended yang diajukan agar mereka berpengalaman menemukan jawaban-jawaban benar sehingga mereka menemukan hal baru (Inprasitha, 2006). Sintaks pembelajarannya terdiri dari enam tahap, yaitu (1) orientasi, (2) penyajian soal terbuka, (3) pengerjaan soal terbuka secara individu, (4) diskusi kelompok tentang soal terbuka, (5) presentasi hasil diskusi kelompok, dan (6) penutup (Murni, 2013; Woranetsudathip \& Yuenyong, 2015).

Namun demikian, bagaimana open ended problem ini disajikan dalam bahan ajar maupun dalam pembelajaran masih belum ada deskripsi yang spesifik. Oleh karena itu, masih perlu ada penelitian dan pengembangan tentang pemuatan open ended problem dalam bahan ajar yang efektif meningkatkan keterampilan berpikir tingkat tinggi. Artikel ini menyajikan hasil penelitian mengenai penerapan open ended problem dalam bahan ajar maupun dalam pembelajaran yang spesifik pada materi luas daerah segiempat dan segitiga di SMP kelas VII.

\section{METODE}

Penelitian ini termasuk penelitian pengembangan (Research and Development) menggunakan modifikasi model pengembangan 4-D (Thiagarajan, Semmel, \& Semmel, 1974). Model pengembangan 4-D terdiri dari empat tahap (stage) yaitu tahap penetapan (define), tahap perancangan (design), tahap pengembangan (develop) dan tahap penyebaran (desseminate). Penyebaran (desseminate) produk pengembangan yang dihasilkan tidak dilaksanakan karena dibutuhkan kajian yang lebih mendalam dan komprehensif. Uji coba dilaksanakan pada 31 siswa SMP Negeri 3 Gangga Kabupaten Lombok Utara Kelas VII Semester II pada tahun pelajaran 2016/2017. Pengumpulan data dilakukan dengan instrumen berupa lembar validasi, lembar angket respons siswa dan tes hasil belajar berbentuk constructed response. Analisis data dilakukan dengan teknik analisis deskriptif.

\section{HASIL DAN PEMBAHASAN}

Penelitian dan pengembangan perangkat ajar ini dilakukan secara bertahap. Tahap awal adalah penetapan (define) dilakukan untuk menggali urgensi penelitian ini diselenggarakan, sekaligus menentukan pijakan utama melalui identifikasi konsep-konsep dasar dengan menelaah Kompetensi Inti dan Kompetensi Dasar kelas VII SMP/MTs pada materi luas daerah segiempat dan segitiga. Hasil dari tahap ini berupa rasional penelitian, peta konsep, dan indikator ketercapaian tujuan. Berdasarkan hasil pada tahap penetapan tersebut kemudian dirancang (design) prototipe bahan ajar. Bahan ajar ini dilengkapi dengan Rencana Pelaksanaan Pembelajaran serta lembar tes hasil belajar. Perangkat pembelajaran tersebut kemudian divalidasi 
oleh dua validator. Validator 1 adalah ahli materi dan pembelajaran matematika, sedangkan validator 2 adalah praktisi pendidikan matematika. Rekapitulasi hasil validasi perangkat pembelajaran ditunjukkan pada tabel 1.

Tabel 1. Rekapitulasi Hasil Validasi Perangkat Pembelajaran

\begin{tabular}{clcccc}
\hline \multirow{2}{*}{ No } & \multirow{2}{*}{ Perangkat Pembelajaran } & \multicolumn{2}{c}{ Rerata Skor Validator Ke- } & \multirow{2}{*}{ Rerata $(\overline{\mathbf{V}})$} & \multirow{2}{*}{ Kriteria } \\
\cline { 3 - 4 } & & $\mathbf{1}$ & $\mathbf{2}$ & & \\
\hline 1 & Bahan ajar & 3,00 & 3,50 & 3,25 & Valid \\
\hline 2 & Rencana Pelaksanaan Pembelajaran & 2,92 & 3,33 & 3,13 & Valid \\
\hline 3 & Lembar Tes Hasil Belajar & 3,28 & 3,57 & 3,43 & Valid \\
\hline
\end{tabular}

Berdasarkan hasil validasi perangkat pembelajaran pada tabel 1 rerata hasil validasi adalah 3,25 yang menunjukkan bahwa bahan ajar memenuhi kriteria valid (Parta, 2009). Rerata hasil validasi pada Rencana Pelaksanaan Pembelajaran adalah 3,13 juga menunjukkan bahwa Rencana Pelaksanaan Pembelajaran memenuhi kriteria valid. Demikian halnya rerata hasil validasi lembar tes hasil belajar adalah 3,43 memenuhi kriteria valid.

Pada tahap pengembangan (develop) bahan ajar dimodifikasi dan direvisi berdasarkan hasil validasi ahli (expert appraisal) dan uji coba (developmental testing). Uji coba dilakukan dalam tiga tahap yaitu uji coba perorangan, uji coba kelompok kecil, dan uji coba kelompok besar (dalam pembelajaran di kelas nyata). Pada tahap uji coba perorangan, fokus utamanya adalah kevalidan bahan ajar secara empiris. Dua siswa diberikan waktu untuk membaca bahan ajar dan diminta untuk mengidentifikasi dua hal yaitu kata-kata atau kalimat yang sulit dipahami dan contoh soal atau masalah yang belum dipahami. Adapun temuan uji coba perorangan disajikan pada tabel 2.

\section{Tabel 2. Temuan pada Uji Coba Perorangan dan Revisinya}

\begin{tabular}{|c|c|c|}
\hline No & Temuan & Revisi \\
\hline 1 & $\begin{array}{l}\text { Kata yang sulit dipahami yaitu "Kompetensi Dasar dan } \\
\text { Indikator "pada halaman IV (romawi), "alternatif" dan } \\
\text { "masalah open ended" pada halaman } 4\end{array}$ & $\begin{array}{l}\text { Penjelasan arti kata sulit sebagai berikut: } \\
\text { a. Kompetensi Dasar adalah kemampuan minimal yang harus } \\
\text { dicapai dalam kegiatan pembelajaran, } \\
\text { b. Indikator adalah respons yang dapat dilakukan atau ditampilkan } \\
\text { oleh siswa dan dapat diukur yang menjadi penanda pencapaian } \\
\text { kompetensi dasar, } \\
\text { c. Alternatif artinya pilihan } \\
\text { d. Masalah open ended artinya masalah matematika yang memiliki } \\
\text { jawaban tidak tunggal, atau jawabannya tunggal tetapi strategi } \\
\text { penyelesaiannya tidak tunggal, atau keduanya. }\end{array}$ \\
\hline 2 & $\begin{array}{l}\text { Pada halaman } 21 \text { kesulitan memahami kalimat "pasangan alas } \\
\text { dan tinggi yang saling berkorespondensi" pada halaman } 21\end{array}$ & $\begin{array}{l}\text { Penjelasan arti kalimat "pasangan alas dan tinggi yang saling } \\
\text { berkorespondensi" adalah alas dan tinggi yang bersesuaian. }\end{array}$ \\
\hline 3 & $\begin{array}{l}\text { Pada halaman } 11 \text { terdapat contoh masalah yang belum } \\
\text { dipahami yaitu nomor } 2 \text { b mengenai keliling lantai yang bisa } \\
\text { ditutupi ubin jika sisi ubin panjangnya } 30 \mathrm{~cm} .\end{array}$ & $\begin{array}{l}\text { Soal nomor } 2 \text { b direvisi menjadi "tentukan keliling lantai yang } \\
\text { mungkin yang bisa ditutupi ubin-ubin tersebut jika sisi ubin } \\
\text { panjangnya } 1 \text { satuan" }\end{array}$ \\
\hline
\end{tabular}

Setelah dilakukan uji coba perorangan, berikutnya dilakukan uji coba kelompok kecil. Uji coba kelompok kecil diarahkan untuk mengetahui kelayakan bahan ajar sebelum digunakan dalam proses pembelajaran pada kelompok yang lebih besar (satu kelas). Ada empat siswa dipilih untuk menilai kelayakan bahan ajar dengan mengisi angket respons yang telah disiapkan. Dari data respons siswa diketahui rerata nilai untuk responden pertama, kedua, ketiga, dan keempat berturut-turut 2,4; 2,$6 ; 2,6 ; 2,5$. Terlihat bahwa rerata nilai masing-masing responden lebih dari dua sehingga masuk kategori respons positif (Parta, 2009). Hal ini menunjukkan bahwa bahan ajar memenuhi kriteria layak digunakan dalam proses pembelajaran pada kelompok yang lebih besar (satu kelas).

Tahapan terakhir adalah uji coba pada kelompok besar yaitu dengan menggunakan bahan ajar dalam pembelajaran di kelas. Hal ini dimaksudkan untuk mengukur dua hal, yaitu kepraktisan dan keefektifan penggunaan bahan ajar. Untuk mengetahui kepraktisan bahan ajar, observer diminta mengamati pembelajaran menggunakan lembar pengamatan pembelajaran. Berdasarkan rekapitulasi hasil observasi keterlaksanaan bahan ajar, diperoleh data rerata skor seluruh aspek semua observer $\left(\overline{O_{A}}\right)$ $=3$,6. Karena nilai $\overline{O_{A}}$ berada pada kisaran $3 \leq \overline{\mathrm{O}}_{A} \leq 4$ disimpulkan bahwa bahan ajar yang dikembangkan praktis (Parta, 2009).

Uji keefektifan penggunaan bahan ajar dinilai berdasarkan beberapa hal yaitu analisis tes hasil belajar, analisis hasil angket respons siswa, serta unjuk kerja siswa dalam menggunakan bahan ajar. Berdasarkan analisis hasil tes penguasaan bahan ajar diperoleh data bahwa 25 dari 31 siswa $(80,64 \%)$ telah mencapai kriteria ketuntasan dengan tingkat penguasaan seluruh kelas $\left(T P_{K}\right)$ sebesar 78,83. Artinya, kriteria yang telah ditentukan yaitu nilai $T P_{K} \geq 75$ telah berhasil dicapai. 
Adapun angket respons yang diberikan pada siswa pada pertemuan terakhir mengungkapkan pengalaman belajar mereka menggunakan bahan ajar. Data yang diperoleh menunjukkan bahwa 29 dari 31 siswa $(93,5 \%)$ memberi respons positif dan skor rerata respons untuk seluruh kelas $\left(\overline{R_{K}}\right)$ adalah 2,35 yang berarti seluruh kelas memberi respons positif $\left(\overline{R_{K}} \geq 2\right)$. Hasil analisis tes hasil belajar dan angket respons siswa disajikan pada tabel 3.

Tabel 3.Hasil Analisis Tes Hasil Belajar dan Angket Respons Siswa

\begin{tabular}{clll}
\hline No & \multicolumn{1}{c}{ Aspek } & \multicolumn{1}{c}{ Penilaian } & \multicolumn{1}{c}{ Kriteria } \\
\hline 1 & Tes hasil belajar & Tingkat penguasaan seluruh kelas adalah 78,83 & Tuntas \\
\hline 2 & Angket respons siswa & Skor rerata respons keseluruhan kelas adalah 2,35 & Respon positif (menerima) \\
\hline
\end{tabular}

Masalah open ended (open ended problems) yang dikembangkan dalam bahan ajar diproyeksikan menjadi stimulus untuk menumbuhkan keterampilan berpikir tingkat tinggi siswa. Hasil unjuk kerja siswa dalam menggunakan bahan ajar memberi deskripsi terhadap keterampilan berpikir siswa yang telah tumbuh. Pertama, siswa dapat menjustifikasi bahwa penggunaan persegi sebagai satuan luas lebih efektif digunakan dibanding satuan luas lainnya seperti segitiga dan lingkaran. Pada gambar 1 ditampilkan cuplikan jawaban siswa 1 .

Cuplikan jawaban siswa 1 tersebut menggambarkan jenis argumentasi sederhana siswa yang dapat menilai efektivitas beberapa alternatif prosedur yang ada. Artinya, siswa sudah dapat memeriksa (checking) pada tingkat berpikir evaluatif (evaluate).

Kedua, siswa telah dapat menjabarkan informasi pada sajian masalah menjadi lebih sederhana sehingga memudahkan menentukan penyelesaian. Hal ini ditunjukkan tatkala menyelesaikan masalah menentukan luas daerah bangun datar yang tidak beraturan. Mereka melihat bahwa bangun datar yang tidak beraturan tersebut merupakan gabungan dari beberapa bangun datar beraturan lain yang luas daerahnya bisa ditentukan dengan cara yang sudah diketahui. Gambar 2 merupakan cuplikan jawaban siswa 2.

Cuplikan jawaban siswa 2 tersebut menunjukkan bahwa siswa dapat mengaitkan unsur-unsur yang berlainan dalam sajian masalah (problem) dengan satu kesatuan strukturnya yang utuh dan mengorganisasikannya dalam menentukan penyelesaian. Hal ini menunjukkan telah terbentuknya kemampuan analisis siswa dalam bentuk yang sederhana.

Ketiga, siswa juga kreatif dalam mengonstruksi masalah sendiri, yaitu menggambar bangun datar sembarang yang terdiri dari gabungan beberapa bangun datar lainnya yang berbeda sekaligus menentukan luas daerahnya. Beragam bentuk berhasil diciptakan, salah satunya seperti terlihat pada gambar 3 .

\section{b. Manakah diantara tiga satuan luas tersebut yang lebih efektif digunakan. Jelaskan alasanmu.}

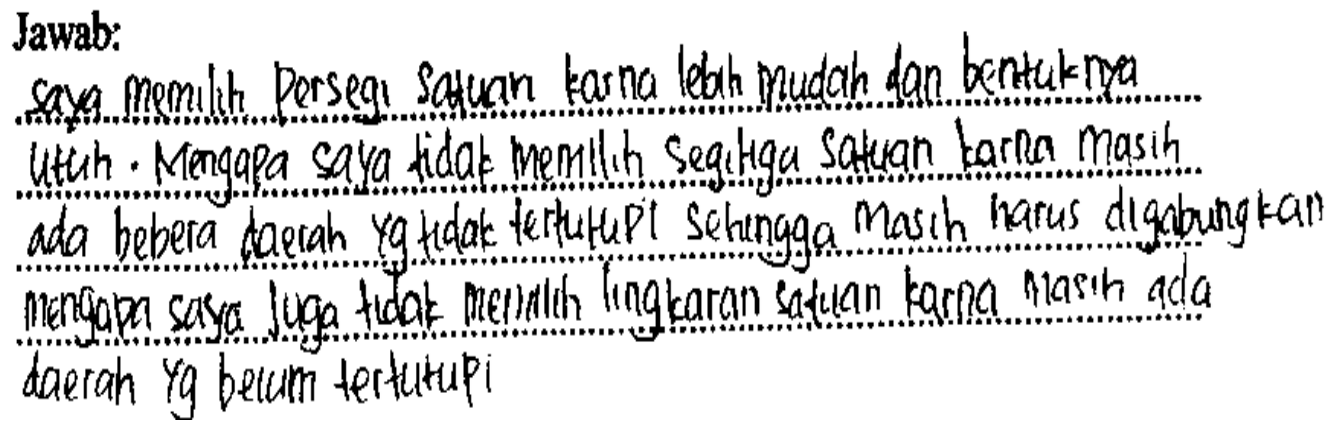

Gambar 1. Cuplikan Jawaban Siswa 1 


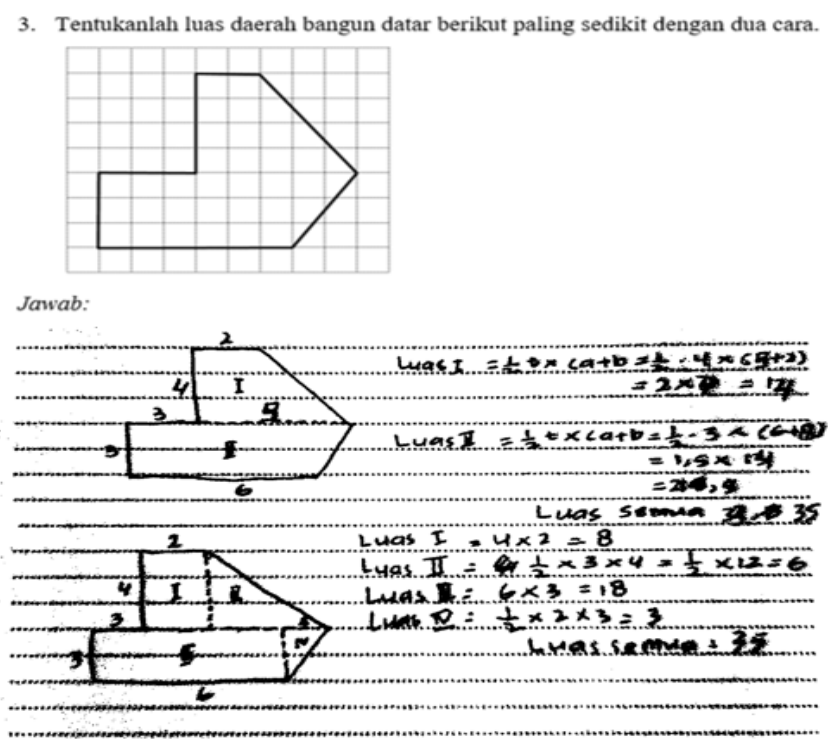

Gambar 2. Cuplikan Jawaban Siswa 2

b. Buatlah soal dengan menggambar gabungan beberapa bangun datar seperi diatas dan tentukan luas daerahnya minimal dengan 2 cara. (ukuran sisi-sisinya terserah kalian). - Jowab:
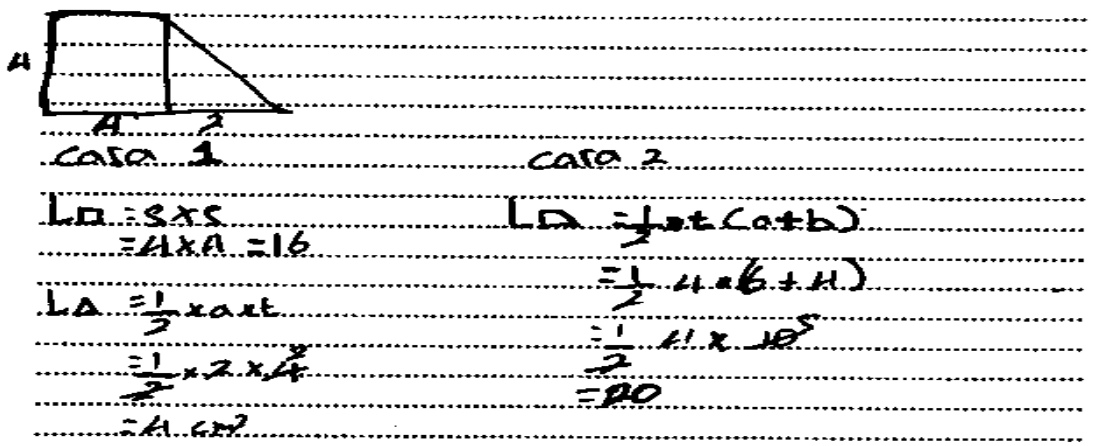

total $=20$

Gambar 3. Cuplikan Jawaban Siswa 3

Dapat disimpulkan berdasarkan hasil analisis tes hasil belajar, analisis hasil angket respons, serta unjuk kerja siswa dalam menggunakan bahan ajar, bahwa penggunaan bahan ajar hasil pengembangan memenuhi kriteria efektif. Terdapat beberapa catatan tambahan selama pelaksanaan uji coba terutama yang berkaitan dengan efektivitas penggunaan bahan ajar. Bahan ajar hasil pengembangan efektif digunakan dipengaruhi juga oleh potensi intrinsik muatan yang dikandungnya. Potensi tersebut antara lain, karena bahan ajar berbasis open ended problem. Hal ini sejalan dengan pendapat yang mengemukakan bahwa kemampuan berpikir siswa bisa dikembangkan dengan membiasakan siswa dengan soal non rutin yang bersifat open ended (As'ari, 2016). Pendapat yang sama juga menyatakan bahwa strategi yang bisa diterapkan untuk mengembangkan keterampilan berpikir tingkat tinggi adalah melibatkan siswa dalam diskusi dengan masalah open ended (Ali \& Mishra, 2014). Gambar 4 merupakan cuplikan contoh open ended problem dalam bahan ajar.

Potensi berikutnya adalah uraian materi yang disajikan menstimulasi siswa untuk mengonstruksi pengetahuan secara mandiri. Hal ini sejalan dengan dasar teori dalam mengembangkan keterampilan berpikir tingkat tinggi yang bergeser dari paradigma transmitting information (hanya memberi pengetahuan) menjadi konstruktivisme (Yen \& Halili, 2015). Gambar 5 merupakan cuplikan uraian materi bahan ajar yang mengandung unsur konstruktivisme. 
1. Diketahui persegi dengan panjang sisi $6 \mathrm{~cm}$. Buatlah 2 persegipanjang yang memiliki luas yang sama dengan luas persegi tersebut pada petak $1 \mathrm{~cm} \times 1 \mathrm{~cm}$ berikut.

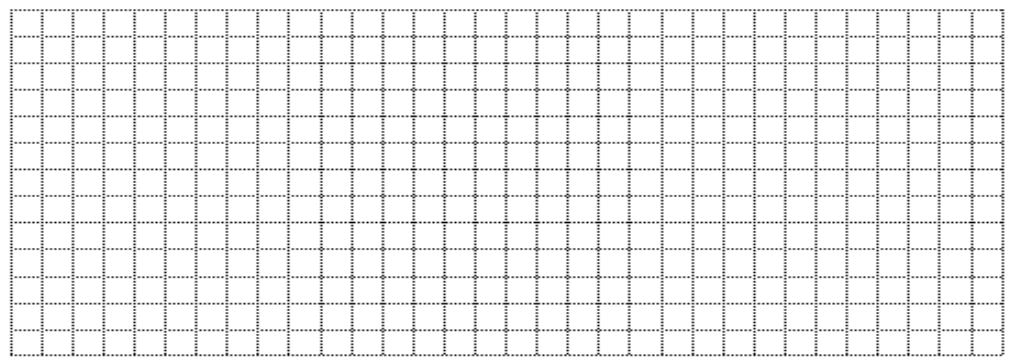

2. Diketahui persegipanjang dengan luas $48 \mathrm{~cm}^{2}$.

Lengkapi tabel berikut dengan ukuranlpanjang dan lebar persegipanjang yang mungkin. (ukuran panjang dan lebar dipilih dari kumpulan bilangan bulat).

\begin{tabular}{|c|c|c|c|}
\hline Persegipanjang & \multicolumn{1}{|c|}{ Panjang } & \multicolumn{1}{c|}{ Lebar } & $\begin{array}{c}\text { Luas } \\
\text { daerah }\end{array}$ \\
\hline 1 & $\ldots \mathrm{cm}$ & $\ldots \mathrm{cm}$ & $48 \mathrm{~cm}^{2}$ \\
\hline 2 & $\ldots \mathrm{cm}$ & $\ldots \mathrm{cm}$ & $48 \mathrm{~cm}^{2}$ \\
\hline 3 & $\ldots \mathrm{cm}$ & $\ldots \mathrm{cm}$ & $48 \mathrm{~cm}^{2}$ \\
\hline 4 & $\ldots \mathrm{cm}$ & $\ldots \mathrm{cm}$ & $48 \mathrm{~cm}^{2}$ \\
\hline
\end{tabular}

\section{Gambar 4. Cuplikan contoh open ended roblem dalam bahan ajar yang dikembangkan}

Perhatikan Gambar 5.1.1 berikut. Gambar 5.1.1 (i) adalah persegipanjang yang daerahnya dibagi dua oleh diagonal, sementara Gambar 5.1.1 (ii) dan 5.1.1 (iii) adalah jajargenjang yang daerahnya juga dibagi dua oleh diagonal.

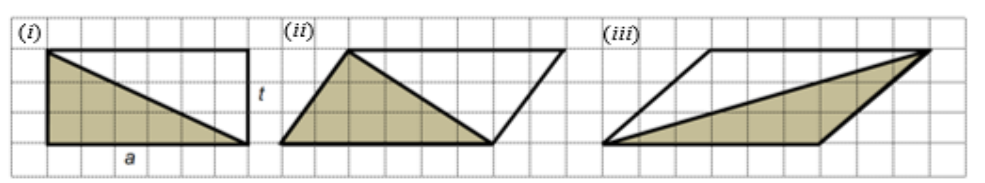

Gambar 5.1.1 Segitiga merupakan separuh jajargenjang

Pada Gambar 5.1.1 (i) terlihat bahwa persegipanjang yang daerahnya dibagi dua oleh diagonal maka masing-masing bagiannya membentuk segitiga yang luasnya sama dan salah satunya diarsir. Segitiga tersebut adalah separuh dari persegipanjang utuh.

Pada pembelajaran sebelumnya (pembelajaran 3) diketahui bahwa persegi panjang maupun jajargenjang pada gambar diatas memiliki luas yang sama.

Mungkinkah kalian bisa menggunakan hubungan antara bangun-bangun tersebut untuk menentukan luas segitiga?

Apakah ketiga segitiga yang diarsir pada gambar 5.1.1 (i), 5.1 .1 (ii), dan 5.1 .1 (iii) diatas memiliki luas yang sama walaupun bentuknya berbeda?

Unsur apa yang menyebabkan luas daerahnya sama atau tidak sama? Jelaskan.

\section{Gambar 5. Cuplikan Uraian Materi Bahan Ajar Konstruktivisme}

Potensi lainnya dari bahan ajar yang dikembangkan efektif digunakan karena memuat masalah yang kontekstual, karena untuk menumbuhkan keterampilan berpikir tingkat tinggi siswa perlu dihadapkan dengan masalah sehari-hari yang kontekstual (Miri et al., 2007). 
Perhatikan peta Pulau Lombok dan Kabupaten Lombok Utara (KLU) yang di blok hitam dalam Gambar 1.1.1 berikut.

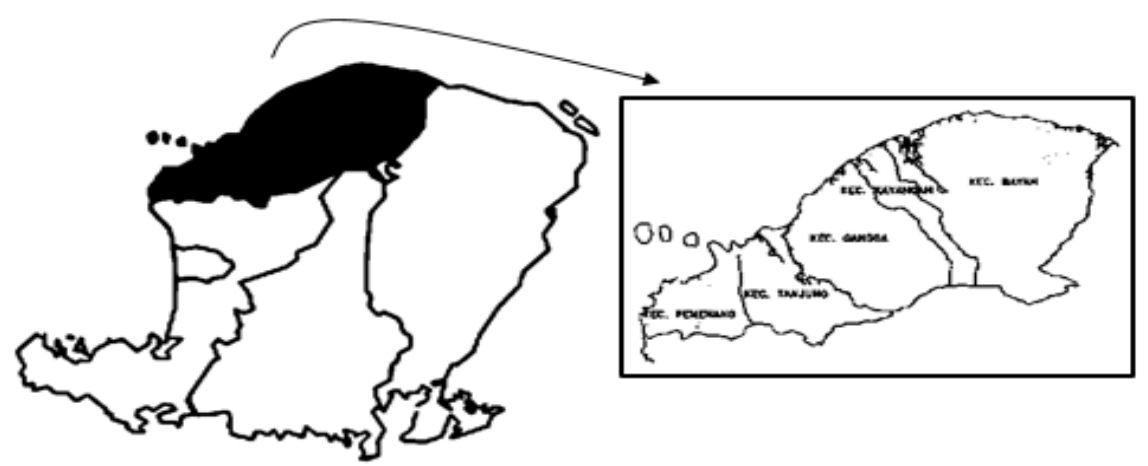

Gambar 1.1.1 Peta Pulau Lombok

Ada 5 kecamatan di Kabupaten Lombok Utara yaitu Pemenang, Tanjung, Gangga, Kayangan dan Bayan. Manakah kecamatan yang lebih luas daerahnya, apakah kecamatan Gangga atau kecamatan Bayan? Jelaskan bagaimana caramu mengetahuinya? Apakah beberapa alternatif berikut ini bisa membantumu?

\section{Gambar 6. Cuplikan Uraian Materi Bahan Ajar Kontekstual}

Alhasil untuk mengembangkan keterampilan berpikir tingkat tinggi diperlukan bahan ajar yang spesifik dan khusus (Heong et al., 2011), dan dikemas dalam bentuk sajian masalah (Suryadi, 2006). Masalah tersebut mengakomodasi diskusi antara siswa dengan tugas-tugas yang memiliki kemungkinan lebih dari satu jawaban benar (Ali \& Mishra, 2014).

\section{SIMPULAN}

Dari hasil penelitian dan pembahasan diperoleh kesimpulan bahwa proses pengembangan perangkat ajar dilakukan melalui beberapa tahap. Tahap pertama adalah menggali urgensi perlunya penelitian ini diselenggarakan, rasional, sekaligus melakukan identifikasi konsep-konsep dasar yang perlu dikuasai oleh siswa. Tahap selanjutnya yaitu menyusun dan memvalidasi desain bahan ajar, Rencana Pelaksanaan Pembelajaran serta lembar tes hasil belajar. Hasil validasi yang dikerjakan oleh validator terhadap perangkat ajar tersebut menyatakan bahwa bahan ajar, Rencana Pelaksanaan Pembelajaran, maupun lembar tes hasil belajar memenuhi kriteria valid. Demikian halnya hasil serangkaian uji coba juga menunjukkan bahwa bahan ajar yang dihasilkan memenuhi kriteria praktis dan efektif.

Analisis terhadap hasil unjuk kerja siswa menunjukkan bahwa penggunaan open ended problem memberi dampak yang signifikan dalam menumbuhkan keterampilan berpikir tingkat tinggi siswa. Siswa antara lain telah dapat menjustifikasi tingkat efektivitas dari beberapa alternatif prosedur yang ada disertai argumentasi yang sesuai, siswa dapat mengaitkan unsurunsur yang berlainan dalam sajian masalah dengan satu kesatuan strukturnya yang utuh dan mengorganisasikannya dalam menentukan penyelesaian, serta siswa berpikir kreatif ditandai dengan kemampuan mengonstruksi masalah sekaligus penyelesaiannya sendiri. Penelitian ini membuka ruang untuk melakukan penelitian berikutnya, seperti penelitian mengenai proses berpikir siswa, pengembangan bahan ajar, dan sebagainya.

\section{DAFTAR RUJUKAN}

Al-Absi, M. (2013). The Effect of Open-ended Tasks - as an assessment tool- on Fourth Graders' Mathematics Achievement, and Assessing Students' Perspectives about it. Jordan Journal of Educational Sciences, 9(3), 345-351.

Ali, S., \& Mishra, M. (2014). Teaching Strategies for Fostering Higher Order Cognitive Skills: The Need of The Globalised Era. Scholarly Research Journal For Humanity Science and English Language, 1(3), 345-354.

As'ari, A. R. (2016). Pengembangan Dimensi Keterampilan Standar Kompetensi Lulusan Kurikulum 2013 Edisi Revisi Ditinjau dari Rumusan Kompetensi Dasar Matematika Jenjang Sekolah Menengah Pertama. In Prosiding Seminar Nasional Matematika dan Pembelajarannya 2016, Fakultas Matematika dan Ilmu Pengetahuan Alam Universitas Negeri Malang (pp. 36-45).

Eggen, P., \& Kauchak, D. (2010). Educational Psychology: Windows on Classroom. New Jersey: Pearson Education, Inc.

Hare, V. C., \& Puliam, C. A. (1980). Teacher Questioning: A Verification and An Extension. Journal of Reading Behavior, 12(1), 69-72. 
Hasim, S. binti M., Yasin, R. binti M., \& Rosli, R. binti. (2015). A Meta Analysis Study on the Effectiveness of Higher Order Thinking Skills (HOTS) Based Learning in Science and Mathematics Subjects. In 7th International Seminar on Regional Education (Vol. 3, pp. 1334-1349).

Heong, Y. M., Othman, W. B., Yunos, J. Bin, Kiong, T. T., Hassan, R. Bin, \& Mohamad, M. M. B. (2011). The Level of Marzano Higher Order Thinking Skills among Technical Education Students. International Journal of Social Science and Humanity, 1(2), 121-125. https://doi.org/10.7763/IJSSH.2011.V1.20

Inprasitha, M. (2006). Open-Ended Approach and Teacher Education. Tsukuba Journal of Educational Study in Mathematics, 25(1), 168-177.

Miri, B., David, B. C., \& Uri, Z. (2007). Purposely Teaching for the Promotion of Higher-order Thinking Skills: A Case of Critical Thinking. Research in Science Education, 37(4), 353-369. https://doi.org/10.1007/s11165-006-9029-2

Murni. (2013). Open-Ended Approach in Learning to Improve Students Thinking Skills in Banda Aceh. International Journal of Independent Reserch and Studies, 2(2), 95-101.

Polya, G. (1965). Mathematical Discovery: On Understanding, Learning, and Teaching Problem Solving. New York: John Wiley and Sons.

Saido, G. A. M., Siraj, S., Nordin, A. B., \& Al-Amedy, O. S. (2015). Teaching Strategies for Promoting Higher Order Thinking Skills: A Case of Secondary Science Teachers. Malaysian Online Journal of Educationla Management, 3(4), 16-30.

Suryadi, D. (2006). Model Bahan Ajar dan Kerangka Kerja Pedagogis Matematika untuk Menumbuhkembangkan Kemampuan Berpikir Matematik Tingkat Tinggi. Mimbar Pendidikan UPI Bandung, 4(25), 45-54.

Thiagarajan, S., Semmel, D. S., \& Semmel, M. I. (1974). Instructional Development for Training Teachers of Exceptional Children. Minnesotta: University of Mennesotta.

Van de Walle, J. A., Karp, K. S., \& Bay-William, J. M. (2010). Elementary and Middle School Mathematics: Teaching Developmentally. USA: Allyn and Bacon.

Woranetsudathip, N., \& Yuenyong, C. (2015). Enhancing Grade 1 Thai Students' Learning about Mathematical Ideas on Addition Through Lesson Study and Open Approach. Mediterranean Journal of Social Sciences, 6(2), 28-33. https://doi.org/10.5901/mjss.2015.v6n2s1p28

Yen, T. S., \& Halili, S. H. (2015). Effective Teaching of Higher Order Thinking (HOT) in Education. The Online Journal of Distance Education and E-Learning, 3(2), 41-47.

Zohar, A. (2004). Elements of Teachers' Pedagogical Knowledge Regarding Instruction of Higher Order Thinking. Journal of Science Teacher Education, 15(4), 293-312. 